Article

\title{
Societal Inclusion in Expert Venues: Participation of Interest Groups and Business in the European Commission Expert Groups
}

\author{
Åse Gornitzka ${ }^{1, *}$ and Ulf Sverdrup ${ }^{2}$ \\ ${ }^{1}$ Department of Political Science and Arena-Centre for European Studies, University of Oslo, 0316 Oslo, Norway; \\ E-Mail: ase.gornitzka@stv.uio.no \\ ${ }^{2}$ Norwegian Institute of International Affairs, 0033 Oslo, Norway; E-Mail: ulf.sverdrup@nupi.no \\ * Corresponding author
}

Submitted: 2 July 2014 | In Revised Form: 1 January 2015 | Accepted: 5 January 2015 |

Published: 31 March 2015

\begin{abstract}
The elaborate system of expert groups that the European Commission organises is a key feature of EU everyday governance and also a potential channel of societal involvement in EU policy making. This article examines the patterns of participation in the expert group system of a broad set of societal actors-NGOs, social partners/unions, consumer organisations, and business/enterprise. The analysis is based on a large-N study of Commission expert groups. Taking on an "executive politics" perspective, we identify main patterns of participation and analyse organisational factors that affect the inclusion of societal actors in the expert group system. We find that such actors are strongly involved in this system. Yet, there is a striking heterogeneity in the extent to which the Commission's administrative units include societal groups as experts in the policy process. The logics that underpin the inclusion of business organisations are not identical to the logics of inclusion applied to social partners and NGOs. The Commission as the core supranational executive is thus selectively open for societal involvement in its expert groups system, and this bureaucratic openness is patterned, clustered, and conditioned by structural factors that affect how the Commission as a multi-organisation operates.
\end{abstract}

\section{Keywords}

Executives; expertise; European Commission; interests groups; organisation; public administration

\section{Issue}

This article is part of the special issue "The Role of Expert Knowledge in EU Executive Institutions", edited by Professor Åse Gornitzka (University of Oslo, Norway) and Dr. Cathrine Holst (University of Oslo, Norway).

(C) 2015 by the authors; licensee Cogitatio (Lisbon, Portugal). This article is licensed under a Creative Commons Attribution 4.0 International License (CC BY).

\section{Introduction}

How public administration relates to societal actors varies considerably between political systemsvariation is seen in how accessible public administration is to different types of societal actors, how these linkages are organised, and what the underlying rationales are. According to principles of responsive and representative public administration the status of unelected bureaucracies rests on acquiring "legitimacy from below" by connecting directly to the society it is supposed to serve (Rothstein, 2012b). At the same time, according to Weberian bureaucratic principles a main source of legitimacy for a responsible bureaucracy is upholding professional standards and applying expertise and specialised information when policies are formulated and implemented (Lægreid \& Olsen, 1978; Olsen, 2006). From this perspective, public administration's relations to society have a different underlying rationale: only to the extent that societal actors carry with them specialised knowledge and information that are instrumental and indispensable to rational policy making processes and effective implementation, would such actors gain access. By including societal actors in- 
to their information system bureaucracies can draw on the expertise that such actors may possess (Saurugger 2006). Hence, for responsive and responsible executive organisations how they deal with the interface between administration, expertise and society in principle becomes important for their legitimacy and effectiveness.

This article examines empirically this nexus-to what extent and under what conditions are different kinds of societal actors included in expert venues for policy making? We analyse these questions in the context of European Union (EU) policy making and the elaborate system of expert groups organised by the EU's executive centre-the European Commission (Commission). This set of expert venues is the most extensive organised supranational information system and a key feature of everyday governance at the EU level, as well as potentially a channel for societal involvement in policy making. Building on previous research on overall patterns of participation (Gornitzka \& Sverdrup, 2010, 2011) we zoom in on societal actors as one of the main types of actors, in addition to national administrations and scientists, that the expertise system is composed of. The Commission as a "normalised" executive (Wille, 2013) can be expected to include societal actors in the way that other executives do. Yet, links with societal groups have been argued to be more important for EU executive bodies than for comparable administrations at national level since the EU's political-administrative system has traditionally had weakly structured connections with society through the "electoral channel". Studies of interest mediation at the European level concur in general that the presence of organised societal and private sector actors has developed into an institutionalized part of EU policy making (Greenwood, 2007, 2011; Mazey \& Richardson, 2001) with the Commission as its most important contact point (Beyers, Eising, \& Maloney, 2008). Considerable scholarship has established how the Commission and societal actors interact through a wide range of modes and means of consultation (see Eising, 2008), yet less is known about how societal actors feature as experts and how they participate in specialised, expert venues.

We unpack the notion of societal actors by looking into participation in the expert group system of a broad set of societal actors-non-governmental organisations (NGOs), social partners/unions, consumer organisations, and business organisations. We know already that such groups are present in the expert group system (see Gornitzka and Sverdrup 2011), but by conducting a more elaborate analysis of the data on participation of societal actors in the Commission's expert groups we can shed further light on what kinds of societal groups are brought into Commission policy making as members of expert groups, which factors affect the inclusion of such actors, and uncover different "logics of inclusion".
We take as our point of departure an "executive politics" perspective (Lodge \& Wegrich, 2012) on the interaction between societal actors and the Commission rather than a theory of interest group politics and strategies (Beyers et al., 2008; Coen, 1998). Consequently, we focus on organisational factors that shape administrative behaviour and develop arguments anchored in organisation theory about how the executive branch of government in general, and the Commission in particular, can be expected to open up for societal participation in the policy making processes through expert venues.

The article proceeds as follows. First we present the analytical framework identifying the factors that can be expected to affect the interaction between the Commission and societal actors. The Commission, like national executives, can be regarded as a multiorganisation where different departments operate in different task environments, under a differentiated and specialised formal structure, and where they are carriers of different traditions, norms and practices. We assume that there is considerable variation among the Commission's Directorate Generals (DGs) in the extent to which they engage with societal actors and see them as relevant experts. Hence, specific arguments that can help explain such variation are introduced. In the subsequent section we give a brief presentation of what an expert group is, and which data and methods are used. Next, the findings on the patterns and configurations of societal participation in the expert group system are presented and discussed. Finally, we conclude by revisiting the main arguments about the nexus between administration, expertise, and society in the light of our main findings.

\section{The Theoretical Arguments: Organisational Factors and the Nexus between Administration, Expertise, and Society}

Societal groups can interact with the executive branch of government in a number of ways, both in the preparation and implementation of policies. National executive bureaucracies vary in how open and pluralistic they are in their contacts with society and how institutionalised these interactions are. There are considerable variations in the rules and norms that regulate this link (Lascoumes \& Le Galès, 2003). As the relationship between society and public administration is a perennial and contested issue in the social sciences (Rothstein, 2012a), the conceptualisations of this relationship are as varied as its empirical manifestations across time and systems. This diversity is also reflected in the scholarship on the role of interest groups and civil society in European politics and governance. The institutionalisation of the European political space (Stone Sweet, Fligstein, \& Sandholtz, 2001) brought interest groups, once mainly organised within nationstates, to the European level as they established trans- 
national networks and associations with representatives in Brussels. As the Commission consolidated its position as the executive centre in the EU, it became a sought-after access point for interest groups more broadly and other societal actors. It also actively promoted the establishment of European level organisations and associations. Interest groups adjusted to the multi-arena policy making stemming from the Europeanisation of public policy in many sectors (Richardson, 2000). As pointed to by Mazey and Richardson (2001), the Commission came to be seen as entertaining "promiscuous relationships" with societal actors, and it became a type of administration where such actors are "pressing against an open door". Strong arguments were made for seeing the European level system of interest intermediation as a system of pluralist lobbying (Andersen \& Eliassen, 1995), but with a bias. The EU as a system of governance was seen to privilege mobile capital interests over diffuse and general societal interests, that is, favouring "businessmen's Europe" (see Pollack, 1997 for a critical examination of this argument).

The main body of research on societal actors in the EU has employed an interest groups politics perspective, taking the interest organisations as the unit of analysis and studying access and strategies for how to influence the EU policy process (Beyers et al., 2008). This article takes executive politics and a public administration perspective as the starting point, shifting the analytical attention to the systematic study of the role of public administration in the formulation and execution of political programmes, and the organisational factors that structure life in political-administrative institutions (Lodge \& Wegrich, 2012), including its interaction with non-government organisations.

According to such a perspective, a key to understanding bureaucratic behaviours, including their openness towards their environment, lies in how an administrative organisation is structured (Simon, 1976[1945]). Public officials do not only look "upward" along the organisational hierarchy and political leadership for guidance and decision making premises. Bureaucratic organisations as open systems can also be expected to seek predictable and regularised relationships with their task environments. Such a conception of executive organisations postulates an interactive relationship between societal actors and public administration. But it does not see bureaucracies as environmentally determined, that is, executives are not the derivative of social forces and agencies prone to be "captured" by the societal actors with whom bureaucracies interact. Rather, public agencies as institutions have a basis for independent action and capacity to manage their relations to external constituents (March \& Olsen, 1989).

Why would executive organisations engage with societal actors? Bureaucracies can, based on an instrumental logic, connect and open up for societal par- ticipation to satisfy, or satisfice (Simon, 1976[1945]), its information needs and for channelling knowledge and information to the appropriate decision-points. Bureaucracies with limited in-house capacity operating in shifting and complicated environments have to rely on external information. Including societal actors is part of their search for information, a search that can be both supply and demand driven (March, 1994), and an essential part of what bureaucracies do. The Commission is no different in this respect from other executive organisations-it might even be more dependent on drawing on outside policy advice and capacity for implementation than national administrations given the nature of the European administrative space. Interest groups carry information that are access goods in their interaction with the Commission (Bouwen, 2004) ${ }^{1}$. The Commission's officials can be expected to be particularly interested in cultivating a relationship with corporate actors and organised interest groups as providers of factual information in complex policy areas (Broscheid \& Coen, 2007; Coen, 1997). In addition, we know from the study of interest group strategies that interest groups and civil society organisations at the EU level are professionalising, which also involves emphasising their qualities as expertise organisations (Saurugger, 2006). Private sector actors may, for instance, possess a type of professional and technical know-how stemming from everyday interaction with sectors of society-a kind of hands-on knowledge that bureaucracies at national or supranational level do not have. Consequently, accessing societal actors' expertise is a likely rationale for the Commission to include such organisations into the policy process.

Societal actors will also have political information, that is, information about sectoral organisations' and grass root preferences. Such preferences could be important for the fate of the Commission's proposals at veto-points in the inter-institutional process of decision making in the EU and for anticipating possible mobilisation of societal actors through media or other means. Furthermore, the inclusion of societal actors into policy making and implementing EU policies can increase the likelihood that such policies are accepted and complied with by affected parties. In this way including societal actors into expert venues can be a way for bureaucracies to monitor and interpret their technical and political environments.

A second set of rationales for societal inclusion concerns bureaucracies as legitimacy seeking organisations acting according to a logic of appropriateness. We know that bureaucratic behaviour is guided by multiple

\footnotetext{
${ }^{1}$ Note that Bouwen's argument refers to the logic of lobbying of business interest in the Commission and the European Parliament within the context of the internal market. The society interests that can be activated as participants in the Commission expert groups are much broader.
} 
norms that reflect different perceptions of what public administration is. Concerns for political loyalty and administrative effectiveness (public administration as an instrument for political leadership), neutrality and professional standards in bureaucratic action ("responsible administration") blend and collide with each other and with concerns for "affected parties" and the sectors it is set to serve ("responsive administration") (Egeberg, 1999). As we have pointed to already, the authority and legitimacy of a bureaucracy can also be derived from its ability to be responsive to socioeconomic interest groups, beyond the instrumental value of including "society" in the formulation and execution of policy. Consequently, there is a potential tension here between the inclusion based on concerns for interest representation and one based on concerns for drawing on a specialised knowledge that such actors bring to the table.

We can expect that in the case of the Commission how such concerns are mixed and balanced will affect the propensity to include societal actors in expert venues. The Commission does not have formal, clear and precise obligations to consult societal actors in general (de Vlieger \& Tanasescu, 2011). Yet, according to norms of a responsive public administration, the Commission is expected to be sensitive to principles of inclusiveness and balanced representation of expertise and interests in its composition of expert groups. If the latter is indeed an active norm in administrative behaviour in the Commission we will expect to see the following patterns. Firstly, inclusion of societal actors in expert venues would be a general feature of the Commission. Secondly, and in line with the notion of pluralistic corporatism, the information system would recognise the need to balance information from different interests in society, especially with respect to the economic cleavage lines (employers versus employees and producers versus consumers). Hence, the Commission can be expected to use a heterogeneity principle in the composition of its expert group system in order to signal balanced representation and avoid allegations of favouritism and "corporate capture".

In sum, establishing and maintaining manageable relationships with organised interest groups, corporate actors, civil society association, etc., would be important for a bureaucracy seeking to secure a stable environment, to enhance its political effectiveness towards other EU institutions (Mazey \& Richardson, 2001), but also for acting according to norms of good, societally responsive administrative behaviour.

However, an executive politics perspective also recognises that bureaucracies are not monolithic structures. Variation in organisational properties within bureaucracies and the environments within which they operate affects their actions, including how they interact with societal actors. Hence, we have to pay attention to possible variations in patterns of societal partic- ipation in expert venues and how such variations can be accounted for.

\subsection{Division of Competencies across Levels of Government}

The Commission is positioned in a multi-level politicaladministrative order and has varying bases for acting independently from member states. This is defined by the distribution of legal competences across levels of government. Legal competences are a basic parameter for the Commission's autonomy of action, and are also a part of the formal structure that varies between the policy domains within which the Commission operates. In some areas the EU holds exclusive competences, in others competences are shared, and in some areas the competences of the EU are more limited and primarily related to supporting and supplementing the national level. Given the propensity of the Commission to build up a transnational civil society in tandem with delegation of power to the supranational level (see above), we expect that the Commission is more likely to include societal actors in areas where the Commission has a strong Treaty basis for independent action thereby underlining its autonomy from member states. In order to test the significance of legal competences for societal inclusion we attributed the competences distribution in the Treaties to the various policy areas: $1=$ supporting/complementary, $2=$ coordinating, $3=$ shared, 4 = exclusive ${ }^{2}$.

\subsection{Bureaucratic Specialisation and Tasks}

The principle of specialisation is the second fundamental organisational property of the Commission-a striking feature of the Commission's administrative apparatus and the portfolio allocation to each Commissioner is that they are arranged along sectoral lines (Egeberg, 2006). From the study of public administration at the national level and several observations on the Commission as a multi-organisation, we can expect to find strong sectorally segmented interaction patterns between the DGs and specialised societal groups. The internal organisation of the Commission affects its interaction with outside constituents. We could, for instance, expect to see DGs dealing with the regulation of the internal market to include business actors more than DGs that relate to other sectors of society. With the data that are available

\footnotetext{
${ }^{2}$ Coding legal competences is difficult. We have used the allocation of competences as they are presented in the treaties. For instance, fishery policy is coded as a policy field where the EU holds exclusive EU competences (value 4), whereas in the field of education and culture the EU holds supporting competences (value 1). Note that the coding has been done regarding policy themes, and not the DG, since a single DG can be involved in policy areas with different legal competences.
} 
to us we cannot examine this in full, but we probe this expectation by looking at overall patterns of participation in expert groups and which DGs that tend to include societal actors in their expert venues.

Bureaucratic organisation also involves the specification of tasks. We can assume that type of primary task of the DG is relevant for their external contact patterns, including their propensity to include societal actors as experts. We assume that internal services departments will not be prone to seek information from outside experts in the same way as DGs involved in specialised sectors of society. We expect that DGs managing the EU's spending programmes and those DGs that develop new legislation are more likely to include the targets of policies in the policy making process compared to DGs that are primarily charged with regulation and enforcement of existing EU law. The latter departments would be more reluctant to potentially compromise their neutrality in the exercise of their tasks. For investigating these expectations we examine a simple frequency distribution of societal inclusion in expert groups according to types of DGs and include this variable in our multivariate model. For categorisation of type of task and coding of DGs we rely on Kassim et al. (2013, pp. 20, 25-26), who use the following categories: internal services/support, external relations of the EU, legislative (producing new legislation) regulatory/enforcement (upkeep and enforcement of acquis communautaire/comitology), research, and spending (management of EU's spending programmes).

Tasks of the administration also vary in the course of a policy process. A standard mode of describing decision making in political systems is to separate the policy-making process into various stages, from agenda setting, policy formulation, decision stage, to implementation and evaluation (Lasswell, 1956). Although studies of actual decision making show that there is often no natural sequence nor clear distinction between the different stages and that these stages are simplifications (Jann \& Wegrich, 2007), separating between policy stages is still analytically helpful for grasping the relationship between administrative task structure and the Commission's inclusion of societal actors. The "stages heuristic" can capture variation in type of actors that participate throughout the policy process (Parag, 2008). This can tell us what type of policy tasks that prompts the Commission to seek such actors' involvement, and what roles the administration assigns to such actors in the policy process. In order to test this relationship we use data on the tasks specified for each expert group. We distinguish between the following tasks: groups that assist the Commission in the preparation of legislation or in policy definition ("Assist in preparation"), suggesting a more technically and specific policy shaping task for expert consultations; groups that provide expertise to the Commission when drafting or implementing measures before the Com- mission submits these draft measures to a comitology committee ("draft implementation"), which is also a highly specialised task; groups that coordinate with member states and promote the exchange of views between actors ("exchange of view- coordination"), which indicates a more loose "forum" function for expert involvement; and groups that monitor the development of national policies and the enforcement of EU policies ("monitoring"), where experts are engaged as watchdogs for the Commission.

\subsection{Institutionalisation and Bureaucratic Traditions}

We can expect bureaucratic traditions for handling policy areas at the European level to affect the openness of the Commission towards societal actors. Some policy fields have been subjected to European governance for a longer period of time than others. According to institutional theory (March \& Olsen, 1995) we could expect that over time, processes of institutionalisation, routinisation, and development of shared experiences, understandings and meanings, might reduce the number of disputes and uncertainties in developing policy and implementing them. Consequently, the Commission can be assumed to have more discretion in older policy fields than in more recent additions to EU executive politics. Hence, in the older fields there is less need to consult with external actors.

The alternative expectation to consider is that also the mode of consultation/interaction in itself, that is, repeated, long-term interaction between the Commission administration and societal groups, becomes routinised and institutionalised. In areas where the Commission is less of an "adolescent bureaucracy" including societal actors may have become a standard operating procedure for processing policy issues (Mazey \& Richardson, 2005). This effect could also be reinforced by formalising the consultative arrangements. If this is indeed a mechanism, we should expect to see more societal inclusion in expert venues that are formal and permanent. Testing these expectations in depth will require qualitative data that our sources do not provide, yet as an approximation we use the variable "portfolio age" based on data on year for the creation of DG portfolios, as measured by Broscheid and Coen (2007), and variables measuring formalisation of Commission's expert groups (expert groups characteristics: formal versus informal and permanent versus temporary).

\subsection{DG Environmental Pressure}

Different DGs face varying types of uncertainties and operate in different task environments. An environmental factor with particular relevance for societal participation is the density of interest groups in a policy area that operate at the European level. Social actors recognise expert groups as an important policy venue, 
and they can use such organised links to further their interests (Peters, 1995) and to legitimise activities visà-vis their own constituency and membership. Business associations target the Commission working level most frequently in their efforts to influence EU decision making (Eising, 2007; Kriesi, Tresch, \& Jochum, 2007). In some policy areas the interest group activity is dense, while in other areas there is a much lower interest group activity (Broscheid \& Coen, 2007; Mazey \& Richardson, 2001). In some areas expertise is to a large extent monopolised by national governments. In these areas the Commission will have less available relevant expertise from societal actors to draw on and also faces less pressure for participation from organised interest groups. This we can expect will influence the Commission's propensity to open up for societal participation. Based on this argument one can expect to see more inclusion of societal actors in expert groups in policy areas where there is a high density of interest groups. In order to examine this relationship we use data from the Coneccs data basis ${ }^{3}$, indicating the number of interest groups operating at the EU level in relation to various DGs.

\section{Data and Methods}

The analysis is based on data from a database of the Commission expert groups (Gornitzka \& Sverdrup, 2011). Formally, an expert group is a consultative entity comprising external experts advising the Commission and our database provides information on key properties of these groups $(\mathrm{N}=1236)$. When constructing the database we used information from the Commission's register of expert groups from January 2007. The database includes all formal and informal groups registered as active at the time ${ }^{45}$. Defining and categorising societal actors is not a straightforward and uncontroversial matter (Beyers et al., 2008). In fact, major political controversy has arisen over this issueespecially whether strong corporate interests have been included guised as expert group members acting in their "personal capacity" (see e.g. Nielsen, 2015). For

3 Consultation, the European Commission and Civil Society (Coneccs) was the Commission's database of civil society organisations active at the EU level. We use data from 2007. http://ec.europa.eu/civil_society/coneccs/index.html

${ }^{4}$ Independent experts assisting the Commission in evaluating proposals and monitor projects in the implementation of activities in the area of research and technological development are not included.

${ }^{5}$ We know that the number of expert groups registered has dropped since 2007 and that some of high end users of expert groups have in absolute terms cut considerably in the number of groups they operate (Hartlapp, Metz, \& Rauh, 2014, pp. 214216), yet how these changes have affected the overall patterns of participation has so far not been documented.

${ }^{6}$ See e.g. https://euobserver.com/justice/127440 the purpose of the analysis presented in this article we use the following broad categories of organisations that are recorded in the registry as members of expert groups: "Enterprises and industry" for organisations representing business interests and for-profit organisations, "Social partners" for organisations representing the interests of European employers and workers (trade unions), "non-governmental organisations-NGOs" for non-profit organisations of general or single societal interests, "consumers" for organisations representing consumer interests, and "practitioners" to cover professional associations. Operationalisations and additional data sources for independent variables used in the analyses are presented and discussed in the theoretical section.

We run three different analyses of societal actors in expert groups. First, we examine the configuration of participants in expert groups. For this purpose we use a simple bivariate correlation analysis. When we examine the organisational factors that affect the inclusion of societal actors in expert groups we use a simple frequency distribution according to the DGs and types of DGs, and a multivariate linear regression model with the participation of societal actors as dependent variable and the expert group as the unit of analysis. The multivariate model used here (Table 5, Table 6 and Appendix) is an elaboration from the Gornitzka and Sverdrup (2011) multivariate model and adds theoretically relevant independent variables to the model by including types of tasks/policy stage and institutionalization of expert venue as variables. This model is also used with different types of societal actors as dependent variables.

The dependent variables are binary codes (participation of a type of actor in an expert group $=1$ versus nonparticipation $=0$ ), hence logistic regression rather than ordinary least square (OLS) is the preferred method. However, as the two methods produce very similar results when the distribution of the dependent variable is not too skewed (about .25/.75) and as OLS coefficients are much more readily interpreted (Christophersen, 2006; Hellevik, 2009; Pohlman \& Leitner, 2003), OLS regression is used for the main model (Table 5). Logistic regression is used for analysis reported in Table 6 and the Appendix.

Some clarifications regarding expert groups are in order. The composition of the group reflects the choices made by the Commission, most of them at the level of DGs and their units. As pointed to earlier, interaction between societal actors and the EU executive bodies does not take place via such expert venues alone-and we make no attempt here to cover the full spectre of societal involvement and the Commission's modes of consultation. The focus here is solely on the expert groups in the Commission. When examining patterns of participation, we should also keep in mind that those actors that are included as experts in such groups do not necessarily become influential. Recent research on the influence of expert groups point to how expert groups vary in their influence on the Commission posi- 
tions (Hartlapp et al., 2014). Our data do not allow us to follow up on the impact of such groups and the extent to which patterns of participation are related to the relative influence of the advice provided by the expert groups on policy making and implementation. Nor can we examine the dynamics and influence of actors within these groups. Roles might be blurred and participants might operate with mixed allegiances (Egeberg, Schaefer, \& Trondal, 2003), e.g. in the case of societal actors, the role of representing particular interests might be blended with an expert-oriented, epistemic role, or it might be moulded by within-group socialisation and deliberations. Consequently, we cannot make claims about the actual behaviour within the expert group system nor the effect that such participation has on the policy content. The type of quantitative analysis of patterns of participation that we conduct here does allow us to make claims about the access of types of actors in the EU's expert venues and this we argue is important for flows of information in EU policy making.

\section{Societal Actors in the Commission's Expert Venues-The Findings}

About 500 expert groups (40 per cent) feature societal actors of different sorts (Table 1, see also Gornitzka and Sverdrup 2011). Since taking part in expert groups represents a more organised kind of interaction between societal actors and the EU executive than bilateral and interest group initiated lobbying, this pattern of participation indicates that the Commission frequently involves societal actors fairly closely in its specialised policy making venues. This could be both the expression of the instrumental value that DGs attach to interacting with societal actors, and a reflection of the norms of openness and inclusion of affected parties, corporate actors and civil society into ordinary policy making at DG unit level/the Commission's administrative level.

These data also uncover that among the societal actors, groups representing business and enterprise are the most frequent participants in the Commission expert groups (present in 29 per cent of the groups), ranking far above the presence of NGOs (Table 1). This might seem to support the idea that the Commission gives privileged access and attention to business/industry expertise, interests and views, indicating a business bias of the Commission's interaction patterns. On the other hand in absolute numbers the presence of NGOs and organisations representing consumer interests is not negligible. And taken together NGOs, consumer and professional organisations are present in more in 28 per cent of the expert groups, that is, they are as frequently included as the businesses/enterprises. Furthermore, these results have to been seen in relation to the pattern of participation of national ministries and agencies: the overall participation of societal actors is in relative terms dwarfed by the dominance of national executives as experts in this type of venue (see Gornitzka and Sverdrup 2011).

Judging from the frequency distribution (Table 1), the presence of social partners and unions (12 per cent of the expert groups) indicates that the expert group system is not primarily a site for traditional corporatist arrangements where the executive meets with peak associations for employees and employers. Hence, the way that the Commission has developed and is using its expert group system is more akin to an organised neopluralist system of interaction between the executive and social actors.

Patterns of co-participation (Table 2) also support such a conclusion-there are strong correlations between the participation of different kinds of societal actors. A principle of heterogeneity also seems to be practiced by Commission DGs in the way committees are composed. The presence of business in an expert group is to some degree balanced by participation from consumer organisations, NGOs and/or social partners/unions.

From Table 3, we see that participation from all societal actors, with the exception of professional organisations/practitioners, is negatively correlated with participation from national ministries, especially in the case of consumer organisations and business/industry. That is, when national executives close to the political apex at the national level interact with the Commission in the expert groups, societal actors are to some extent excluded from participating. There is no such negative relationship found for groups where national agencies participate-societal actor and agency participation is not significantly correlated. Scientists on the other hand tend to participate together with societal actors, with the exception of consumer organisations. Hence, we can conclude that DG units bring together a mixed set of societal actors and scientists in venues separate from the expert groups that bring DG units in interaction with member states' ministries.

Table 1. Number and Type of Societal Actors Participating in European Commission Expert Groups. 2007. N = 1236.

\begin{tabular}{lcc}
\hline $\begin{array}{l}\text { Type of societal } \\
\text { actors }\end{array}$ & N & $\begin{array}{c}\text { Percentage of all } \\
\text { expert groups }\end{array}$ \\
\hline $\begin{array}{l}\text { Enterprises and } \\
\text { industry }\end{array}$ & 352 & 29 \\
$\begin{array}{l}\text { Social partners/ } \\
\text { unions }\end{array}$ & 146 & 12 \\
NGOs & 207 & 17 \\
$\begin{array}{l}\text { Consumer } \\
\text { organisations }\end{array}$ & 96 & 8 \\
$\begin{array}{l}\text { Practitioners } \\
\text { All types of }\end{array}$ & 156 & 13 \\
societal actors & 498 & 40 \\
\hline
\end{tabular}

Source: Own data, see also Gornitzka and Sverdrup (2011, p. 55). 
Table 2. Co-participation of types of societal actors in European Commission wxpert groups 2007. Bivariate Correlations Pearson's R. N = 1236.

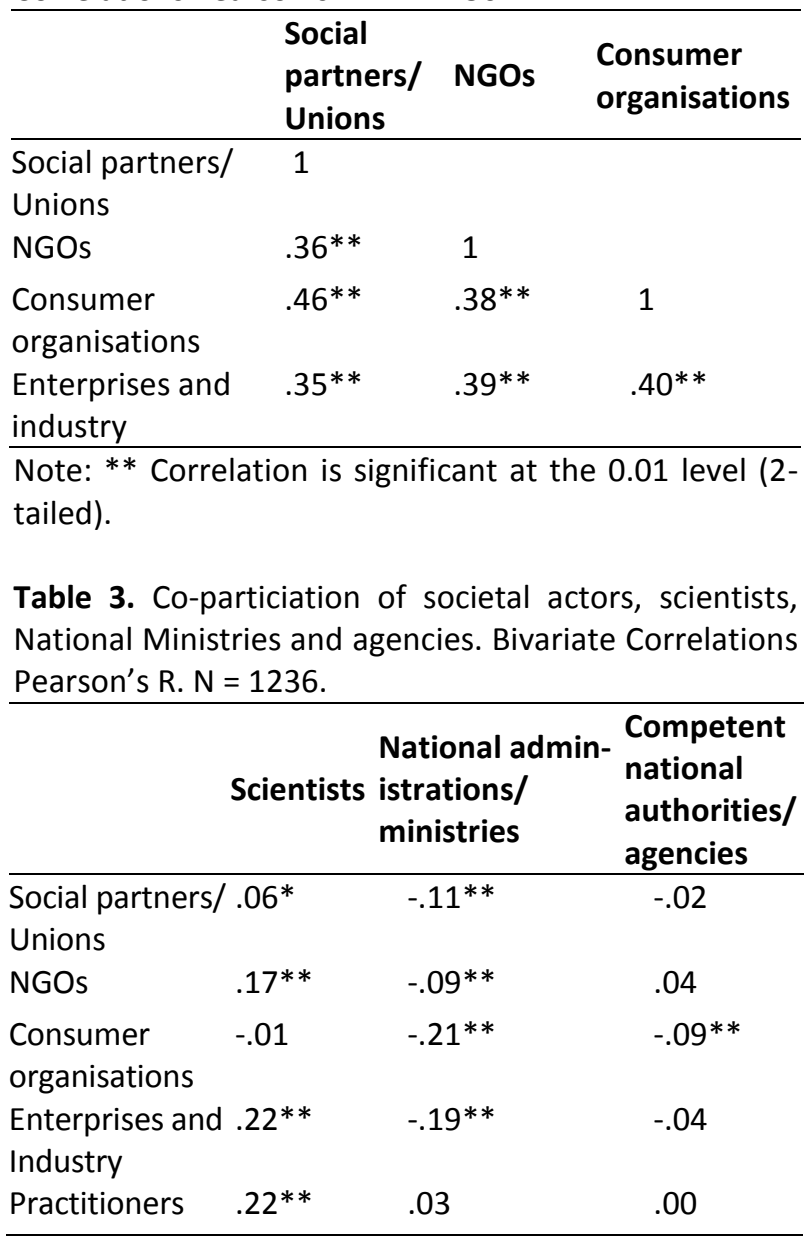

Notes: ${ }^{* *}$ Correlation is significant at the 0.01 level (2tailed); * Correlation is significant at the 0.05 level (2tailed). Source: Own data.

\subsection{Variation according to Commission DGs}

Figure 1 maps the distribution of the number of expert groups that include societal actors and relates it to the total number of expert groups per DG. Most DGs that dispose over a set of expert groups also organise groups where societal actors participate. Yet, as expected, there is strong variation across policy areas when it comes to degree of societal actors' participation. In absolute numbers the DGs for Research \& Development, Environment, as well as DG Enterprise, organise most of the expert groups where societal actors participate. Relatively speaking, also DG Education \& Culture and DG for Agriculture are open to societal involvement, as these DGs also include such actors into a majority of their expert groups. We see also that the DGs that have spending the EU budget (distributive/redistributive policy fields) as its core task organise the biggest share of the groups where societal actors are included as experts (Table 4).

We also note that only two of the DGs that are high end users of expert groups in their policy making seem to exclude societal actors-this is the case for policy making for taxation and customs, and for the production of EU statistics. Already from this overview we see that the Commission does not approach the inclusion of societal actors according to one overall "logic". On the whole there are few obvious common characteristics to the DGs that are most open for interaction with industry/enterprise, NGOs or other societal actors through their use of expert groups. This underscores the need to identify underlying factors that can account for this variation.

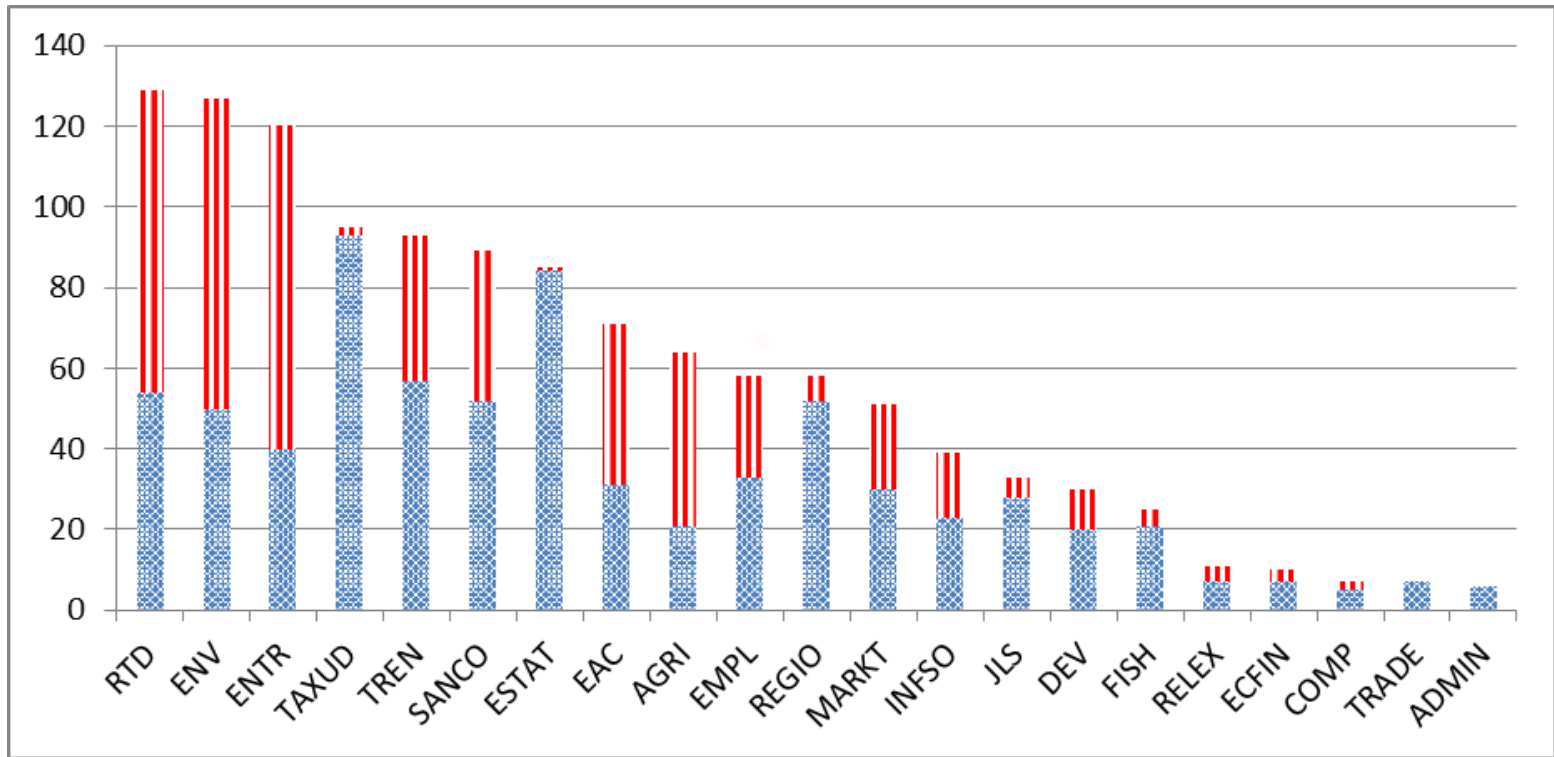

Figure 1. Number of European Commission expert groups with (in blue) and without (in red) participation of societal actors according to DG (2007). Only DGs with more than 5 expert groups included. Source: Own data. 
Table 4. Number of expert groups with participation from societal actors according to type of DG (Main Task of DG) N = 1236.

\begin{tabular}{|c|c|c|c|c|c|c|c|}
\hline \multirow[b]{2}{*}{$\begin{array}{l}\text { Expert groups with } \\
\text { participation from }\end{array}$} & \multicolumn{6}{|c|}{ Type of DGs - classified according to main task } & \multirow[b]{2}{*}{ Total } \\
\hline & $\begin{array}{l}\text { External } \\
\text { Relations }\end{array}$ & $\begin{array}{l}\text { Internal } \\
\text { policy and } \\
\text { services }\end{array}$ & Legislative & $\begin{array}{l}\text { Regulation/ } \\
\text { Enforcement }\end{array}$ & Research & Spending & \\
\hline Societal actors (overall) & 14 & 8 & 143 & 112 & 3 & 218 & 498 \\
\hline$\%$ within societal actors & $2,8 \%$ & $1,6 \%$ & $28,7 \%$ & $22,5 \%$ &, $6 \%$ & $43,8 \%$ & $100,0 \%$ \\
\hline NGOs & 11 & 1 & 84 & 55 & 3 & 53 & 207 \\
\hline$\%$ within NGO & $5,3 \%$ &, $5 \%$ & $40,6 \%$ & $26,6 \%$ & $1,4 \%$ & $25,6 \%$ & $100,0 \%$ \\
\hline Social Partners/ Unions & 5 & 1 & 36 & 40 & 0 & 64 & 146 \\
\hline $\begin{array}{l}\% \text { within Social } \\
\text { Partners/Unions }\end{array}$ & $3,4 \%$ &, $7 \%$ & $24,7 \%$ & $27,4 \%$ &, $0 \%$ & $43,8 \%$ & $100,0 \%$ \\
\hline Industry/Enterprise & 6 & 3 & 87 & 81 & 3 & 172 & 352 \\
\hline $\begin{array}{l}\% \text { within } \\
\text { Industry/Enterprise }\end{array}$ & $1,7 \%$ & ,9\% & $24,7 \%$ & $23,0 \%$ & $9 \%$ & $48,9 \%$ & $100,0 \%$ \\
\hline Consumers & 0 & 0 & 18 & 53 & 0 & 25 & 96 \\
\hline$\%$ within Consumers &, $0 \%$ &, $0 \%$ & $18,8 \%$ & $55,2 \%$ &, $0 \%$ & $26,0 \%$ & $100,0 \%$ \\
\hline Practitioners & 7 & 6 & 47 & 44 & 0 & 52 & 156 \\
\hline$\%$ within Practitioners & $4,5 \%$ & $3,8 \%$ & $30,1 \%$ & $28,2 \%$ &, $0 \%$ & $33,3 \%$ & $100,0 \%$ \\
\hline
\end{tabular}

Source: Own data.

Table 5. Regression analysis of inclusion of societal actors in Commission expert groups. OLS regression. $\mathrm{N}=1127$.

\begin{tabular}{|c|c|c|c|c|}
\hline \multirow[t]{2}{*}{ Model } & \multicolumn{2}{|c|}{$\begin{array}{l}\text { Unstandardized } \\
\text { Coefficients }\end{array}$} & \multirow{2}{*}{$\begin{array}{c}\begin{array}{c}\text { Standardized } \\
\text { Coefficients }\end{array} \\
\text { Beta } \\
\end{array}$} & \multirow[t]{2}{*}{ Sig. } \\
\hline & B & Std. Error & & \\
\hline (Constant) & ,053 & ,079 & & \\
\hline Legal competences in policy area & ,015 & ,017 & 029 & Not sign \\
\hline$D G$ main task (Spending $=1, E l s e=0)$ & 118 & ,033 & 115 & $* * *$ \\
\hline \multicolumn{5}{|l|}{ Policy cycle } \\
\hline - Assist in policy preparation & ,079 & ,034 & ,078 & $*$ \\
\hline - Coordinate/exchange views &,- 032 & ,034 &,- 032 & Not sign \\
\hline - Draft implementation & ,025 & ,041 & ,019 & Not sign \\
\hline - Monitoring national level &,- 083 &, 044 &,- 054 & Not sign \\
\hline Formal (1) /informal (0) group & ,006 &, 035 &, 005 & Not sign \\
\hline Permanent (1)/temporary (0) group &, 024 & ,032 & 024 & Not sign \\
\hline Policy Age & ,001 & ,001 & 034 & Not sign \\
\hline $\begin{array}{l}\text { DG unit environment } \\
\text { - Number of interest groups } \\
\text { Adiusted } R^{2}=10\end{array}$ &, 002 & ,000 & 268 & $* * *$ \\
\hline
\end{tabular}

Notes: ${ }^{*}$ significant at 0.05 level; ${ }^{* *}$ significant at 0.01 level; ${ }^{* * *}$ significant at 0.005 level; Source: Own data.

\subsection{Factors Affecting Inclusion of Societal Actors in Expert Group System}

Our multivariate analyses (Table 5), in which the explanatory value of the different predictors is assessed simultaneously, show that overall our expectations concerning the impact of organisational factors on patterns of inclusion are only partially supported. External pressures that DG units face is the single most important factor that can explain why some DG units incorporate societal actors as experts in the policy process-executive units seem to respond to pressure for participation and the availability of expertise from organised societal interests in their task environment ${ }^{7}$. The more organised interest groups there are in a DG's policy domain, the more it opens up for participation of societal actors in the policy process. We find this link for all types of societal actor participation (see Table 6).This ties in with Chalmers' (2013) findings on how interest groups characteristics (resources and European orientation) affect the number of seats interest organisations get in Commission expert groups (Chalmers, 2013). Yet, our findings do not neces-

\footnotetext{
7 These findings are consistent with Gornitzka and Sverdrup (2011) who find similar effect of this variable as well as no significant effects of portfolio age and legal competences.
} 
sarily imply that the Commission's interaction with society is environmentally determined. Nor does the fact that interest group density DGs face in their task environment is a significant factor accounting for variation in patterns of participation give us reason to believe that the overall patterns of participation are the consequence of "agency capture" by strong corporate actors.

Our findings show that also characteristics on the side of the executive are factors that affect patterns of inclusion. As expected, spending DGs are more inclusive than DGs with other tasks, also when controlled for other factors. DG units also seem to deem the expertise of societal groups as more relevant and legitimate in the preparatory stage than in the implementing stages of the policy process (weak, but statistically significant effect). Yet, the considerable diversity in the use of societal actors in expert groups within the different parts of the Commission is far from being fully accounted for by this multivariate model. Moreover, when we unpack the category "societal actors" some differences in the "logic of inclusion" of DGs come to the fore (Table 6).

Firstly, although formal legal parameters for the Commission's autonomy in general do not affect its propensity for interacting with societal actors in its expert group system (Table 5), DGs more often include business and consumer organisations in policy areas where the Commission has a stronger basis for independent action than in areas where EU competences are low. This supports the idea that both sides of the market (suppliers and consumers) are part of a transnational expertise structure that the Commission as a responsive and responsible executive can draw on in areas that form the core of the EU's competences. However, for DG units' openness towards social partners/unions and NGOs there are no significant effects of formal competences when controlling for other factors. Hence, we could argue that the DGs' behaviour does not seem to go in the direction of reproducing corporatist arrangements with unions and employer organisation in areas where the EU has taken over the competences from the member states.

Secondly, the DGs' type of task has a relatively strong effect on inclusion of private sector actors and NGOsbut in different ways: NGOs are less likely to be included in expert venues for DGs with distributive tasks than for other DGs, whereas industry and enterprises are more likely to be included. As the simple distribution displayed in Table 4 underlines, NGOs are present in expert groups for DGs that produce new EU legislation.

This brings us to a third relevant finding on the complex relationship between stages in the policy process and inclusion of societal actors. Overall it is clear that DGs differentiate between social partners versus private sector actors according to what kind of role they assign to expert groups. Social partners are brought into these venues for assisting the Commission in monitoring implementation and developments at the national level. DGs tend to exclude both business and professional associations from this type of expertise function. The latter two groups are significantly more likely to be included when the Commission wants assistance in preparing policies (Table 6). Commission DGs include social partners also in groups that have a more general function facilitating the "exchange of views", and less specialised expert venues. So the inclusion of business actors is not ubiquitous, but clustered around some stages of the policy process over others. For NGOs' participation there are no significant effects of this aspect of the Commission's task structure.

Table 6. Summary of main findings-Regression analysis of various societal actors to commission expert groups: Social Partners/Unions; Industry/enterprise; Consumers; NGOs. Logistic regression*. N = 1127.

\begin{tabular}{|c|c|c|c|c|c|}
\hline Model & $\begin{array}{c}\text { Social } \\
\text { partners } \\
\text { Unions }\end{array}$ & $\begin{array}{l}\text { Industry/ } \\
\text { Enterprise }\end{array}$ & Consumers & NGOs & Practitioners \\
\hline \multicolumn{6}{|l|}{ Legal competences in policy area } \\
\hline & / & POS & POS & / & / \\
\hline \multicolumn{6}{|l|}{ DG main task } \\
\hline (spending $=1$, else $=0$ ) & / & POS & / & NEG & / \\
\hline \multicolumn{6}{|l|}{ Policy cycle } \\
\hline - Assist in policy preparation & / & POS & / & / & POS \\
\hline - Coordinate/exchange views & POS & / & / & / & / \\
\hline - Draft implementation & / & / & / & / & / \\
\hline - Monitoring national level & POS & NEG & / & / & NEG \\
\hline Formal (1) / informal (0) group & POS & / & POS & POS & NEG \\
\hline Permanent(1) /temporary (0 group) & / & / & POS & / & / \\
\hline Portfolio age & POS & POS & POS & / & / \\
\hline \multicolumn{6}{|l|}{ DG unit environment } \\
\hline - Number of interest groups & POS & POS & POS & POS & POS \\
\hline Nagelkerke's pseudo $R^{2}$ & .13 & .19 & .24 & .10 & .07 \\
\hline
\end{tabular}

Notes: / = Not significant; POS = positive coefficients, significant; NEG = negative coefficients, significant; * See Appendix for full results from regression analyses. Source: Own data. 
Fourthly, the extent to which the Commission opens up for societal actor participation varies systematically according to the institutionalisation and the maturity of the DGs. When controlling for the effect of the other variables, the DGs operating in mature portfolios where the Commission has a long history are more likely to include social partners, business, and consumer organisations than DGs with responsibilities in more recent additions to the Commission's portfolios. Thus far we can conclude that a DG unit's "coming of age" matters for its external links to some of the societal actors, but not for all. The institutionalisation of the expert group itself also has significant effect: unlike scientists that tend more often to appear in informal groups (Gornitzka and Sverdrup 2010), the participation of societal actors is anchored in formal settings. There are two exceptions to this main pattern-for business inclusion this variable is not significant whereas practitioners/professional associations are less likely to be included in expert venues that are formalised.

\section{Conclusions}

The analysis of patterns of participation in the Commission's expert groups portrays the Commission as an open executive that has established an extensive ad-hoc organisation for policy making and implementation. This system includes societal actors to a large extent-such actors took part in almost 500 groups and committees (40 per cent of all expert groups). It seems that this mode of interaction has become a standard operating procedure for the European executive to involve societal actors in the policy process along with other modes of consultation (Greenwood 2011). The pattern of inclusion of societal actors we find is consistent with the Commission acting as a responsive and responsible executive that opens up its expert venues to interest organisations' specialised knowledge and expertise as well as to a heterogeneous set of societal interests.

Within the set of societal actors that are included in the expert groups, business actors are as a single group the most prevalent. Seemingly these results lend support to the claim that European business has privileged access to EU governance sites and expert venues. However, this conclusion needs to be qualified based on our observations. Firstly, taken together, NGOs, and consumer and practitioners' organisations are included in the expert group system as frequently as businesses and enterprises. Secondly, as demonstrated in previous analysis (Gornitzka \& Sverdrup, 2011), in the total system of expert groups, business actors are outnumbered by representatives from national ministries and agencies-national level executives are the Commission's prime interlocutor in this venue. More than a business bias the Commission has a "national executive bias" - the expert groups system is primarily (but not only) the "asteroid belt" of the EUs executive centre that links it to national administrations. Thirdly, we find that expert groups where societal actors participate are organised arenas for co-production and coimplementation of policy. Several types of societal actors-business and enterprise, social partners, consumer organisations, NGOs-interact with DG units within these multi-actor, ad-hoc venues, along with scientists and practitioners. These data of course cannot tells us whether there are other systematic biases, for instance according to interest group resources (Chalmers, 2013), in whom the Commission counts as experts. We have seen that DGs respond to the density of interest organisation in their policy environment. Still, the Commission's DG units themselves control the organisation and composition of their groups and the overall patterns of inclusion/exclusion of societal actors are partly consistent with a norm of participatory diversity and representation of heterogeneous interests and perspectives. As concerns "corporate capture" of expert venues what we do see is that business interests are within the group setting more often than not matched and mixed with other non-governmental actors.

The second major pattern is the variegated ways in which the Commission interacts with European societal actors through the use of expert groups. There is a striking heterogeneity in the way that societal involvement in the Commission's expert groups is clustered around certain policy fields. We have also seen that the political organisation that DG units are faced with in their portfolio environment affects their propensity to include societal actors as experts-the denser a policy domain is populated with interest groups at the EU level, the more the DGs are likely to open up for their participation.

The multivariate analysis shows that executive administrative units' varying competences, task structures, and level of institutionalisation are relevant determinants of societal inclusion, but these organisational factors matter in different ways for different types of actors. This suggests that there are systematic differences in the logic underlying the DGs' interaction with societal groups in this particular organised setting and that such actors play varying roles in the executive politics of the EU through their participation in the expert groups. An observable indication is the way that the Commission's task structure matters as a conditioning factor-business actors tend to be included as experts by the DGs in the preparatory stage and for drafting implementing measures, and excluded from monitoring policy implementation. Social partners, on the other hand, are deemed as relevant and legitimate experts and likely to be included in monitoring implementation. Our analysis also shows that the maturity of the Commission's DGs is important for how it interacts with its environment. The more mature portfolios will tend to include social partners, business and consumer organisations. 
At the level of expert groups we also see the effects of institutionalisation: our findings support the view that the Commission has institutionalised its involvement with social partners, consumer organisations, and NGOs. The role of such actors in the policy process is formally anchored and seems to be sustained by bureaucratic norms, practices, and routines in some parts of the Commission. The Commission as the core executive is thus selectively open for societal involvement in its expert groups system. However, this bureaucratic openness is not erratic but patterned, clustered, and conditioned by structural factors that affect how the Commission as a multi-organisation operates.

\section{Acknowledgements}

This article has been presented at panels at the ECPR General Conference September 2014 in Glasgow and National Conference in Political Science, January 2015 in Oslo. We are grateful for the valuable comments from panel participants and in particular from Rune Dahl Fitjar.

\section{Conflict of Interests}

The authors declare no conflict of interests.

\section{References}

Andersen, S. S., \& Eliassen, K. A. (1995). EU lobbying: The new research agenda. European Journal of Political Research, 27(4), 427-441. doi: 10.1111/ j.1475-6765.1995.tb00478.x

Beyers, J., Eising, R., \& Maloney, W. (2008). Researching interest group politics in Europe and elsewhere: Much we study, little we know? West European Politics, 31(6), 1103-1128. doi: 10.1080/01402380 802370443

Bouwen, P. (2004). The logic of access to the European Parliament: Business lobbying in the committee on economic and monetary affairs. Journal of Common Market Studies, 42(3), 473-496.

Broscheid, A., \& Coen, D. (2007). Lobbying activity and fora creation in the EU: Empirically exploring the nature of the policy good. Journal of European Public Policy, 14(3), 346-365.

Chalmers, A. W. (2013). Getting a seat at the table: Capital, capture and expert groups in the european union. West European Politics, 37(5), 976-992. doi: 10.1080/01402382.2013.852832

Christophersen, K.-A. (2006). Databehandling og statistisk analyse med SPSS. Oslo: Unipub.

Coen, D. (1997). The evolution of the large firm as a political actor in the European Union. Journal of European Public Policy, 4(1), 91-108.

Coen, D. (1998). The European business interest and the nation state: Large-firm lobbying in the
European Union and member states. Journal of Public Policy, 18(01), 75-100.

de Vlieger, P., \& Tanasescu, I. (2011). Changing forms of interactions between the European Commission and interest groups: The case of religious lobbying. Journal of European Integration, 34(5), 447-463. doi: 10.1080/07036337.2011.595485

Egeberg, M. (1999). The impact of bureaucratic structure on policy making. Public Administration, 77(1), 155-170.

Egeberg, M. (2006). Balancing autonomy and accountability: Enduring tensions in the European Commission's development. In M. Egeberg (Ed.), Multilevel union administration. The transformation of executive politics in Europe (pp. 31-50). Houndmills: Palgrave MacMillan.

Egeberg, M., Schaefer, G. F., \& Trondal, J. (2003). The many faces of EU committee governance. West European Politics, 26(3), 19-40.

Eising, R. (2007). Institutional context, organizational resources and strategic choices. European Union Politics, 8(3), 329-362.

Eising, R. (2008). Interest groups in EU policy-making. Living Reviews in European Governance, 3(4).

Gornitzka, Å., \& Sverdrup, U. (2010). Enlightened decision making? The role of scientists in EU governance. Politique Europénne, 32(3).

Gornitzka, Å., \& Sverdrup, U. (2011). Access of experts: Information and EU decision-making. West European politics, 34(1), 48-70.

Greenwood, J. (2007). Organized civil society and democratic legitimacy in the European Union. British Journal of Political Science, 37(02), 333-357. doi: doi:10.1017/S0007123407000166

Greenwood, J. (2011). Interest representation in the European Union. Basingstoke: Palgrave Macmillan.

Hartlapp, M., Metz, J., \& Rauh, C. (2014). Which policy for Europe? Power and conflict inside the European Commission. Oxford: Oxford University Press.

Hellevik, O. (2009). Linear versus logistic regression when the dependent variable is a dichotomy. Qual Quant, 43(1), 59-74.

Jann, W., \& Wegrich, K. (2007). Theories of the policy cycle. In F. Fischer, G. J. Miller \& M. Sidney (Eds.), Handbook of public policy analysis: Theory, politics and methods (pp. 43-62). Boca Ratoon, FL.: CRC Press.

Kassim, H., Peterson, J., Bauer, M. W., Connolly, S. J., Dehousse, R., Hooghe, L., \& Thompson, A. (2013). The European Commission of the twenty-first century. Oxford: : Oxford University Press.

Kriesi, H., Tresch, A., \& Jochum, M. (2007). Going public in the European Union-Action repertoires of Western European collective political actors. Comparative Political Studies, 40(1), 48-73.

Lascoumes, P., \& Le Galès, P. (2003). Interests groups and public organisations in Europe. In B. G. Peters \& 
J. Pierre (Eds.), Handbook of public administration (pp. 322-331). Thousand Oaks: Sage. doi: DOI: 10.4135/978-1-84860-821-4.n25

Lasswell, H. D. (1956). The decision process: Seven categories of functional analysis. College Park, Maryland: University of Maryland Press.

Lodge, M., \& Wegrich, K. (2012). Public administration and executive politics: Perennial questions in changing contexts. Public Policy and Administration, 27(3), 212-229. doi:10.1177/0952076712438724

Lægreid, P., \& Olsen, J. P. (1978). Byråkrati og beslutninger: En studie av norske departement. Bergen: Universitetsforlaget.

March, J. G. (1994). A primer on decision making: How decisions happen. New York: The Free Press.

March, J. G., \& Olsen, J. P. (1989). Rediscovering institutions: The organizational basis of politics. New York: Free Press.

March, J. G., \& Olsen, J. P. (1995). Democratic governance. New York: Free Press.

Mazey, S., \& Richardson, J. (2001). Institutionalizing promiscuity: Commission-interest group relations in the European Union. In A. Stone Sweet, W. Sandholtz, \& N. Fligstein (Eds.), The institutionalization of Europe (pp. 71-93). Oxford: Oxford University Press.

Mazey, S., \& Richardson, J. (2005). Environmental groups and the EC: Challenges and opportunities. In A. Jordan (Ed.), Environmental policy in the European Union (2nd ed., pp. 106-121). London: Earthscan.

Nielsen, N. (2015). Top officials demand transparency on EU expert groups. Euobserver. Retrieved from https://euobserver.com

Olsen, J. P. (2006). Maybe it is time to rediscover bureaucracy. Journal of Public Administration Research and Theory, 16(1), 1-24. doi:10.1093/ jopart/mui027
Parag, Y. (2008). Who governs the air we breathe? Lessons from Israel's industrialist covenant. Journal of Environmental Policy \& Planning, 10(2), 133-152. doi:10.1080/15239080801928402

Peters, B. G. (1995). The politics of bureaucracy. New York: Longman Publishers USA.

Pohlman, J. T., \& Leitner, D. W. (2003). A comparison of ordinary least squares and logistic regression. The Ohio Journal of Science, 103(5), 118-125.

Pollack, M. A. (1997). Representing diffuse interests in EC policy-making. Journal of European Public Policy, 4(4), 572-590. doi:10.1080/135017697344073

Rothstein, B. (2012a). Administration and society. In B. G. Peters \& J. Pierre (Eds.), The Sage handbook of public administration (pp. 403-405). London: Sage.

Rothstein, B. (2012b). Political legitimacy for public administration. In B. G. Peters \& J. Pierre (Eds.), The Sage handbook of public administration (2nd ed., pp. 407-419). London: Sage Publications.

Saurugger, S. (2006). The professionalisation of interest group representation: A legitimacy problem for civil society in the EU? In S. Smismans (Ed.), Civil society and legitimate European governance (pp. 260-276). Cheltenham: Edward Elgar.

Simon, H. A. (1976[1945]). Administrative behavior: A study of decision-making processes in administrative organization (3rd ed.). New York: Free Press.

Stone Sweet, A., Fligstein, N., \& Sandholtz, W. (2001). The Institutionalization of European Space. In A. Stone Sweet, W. Sandholtz, \& N. Fligstein (Eds.), The institutionalization of Europe (pp. 1-28). Oxford: Oxford University Press.

Wille, A. (2013). The normalization of the European Commission. Politics and bureaucracy in the EU executive. Oxford: Oxford University Press.

\section{About the Authors}

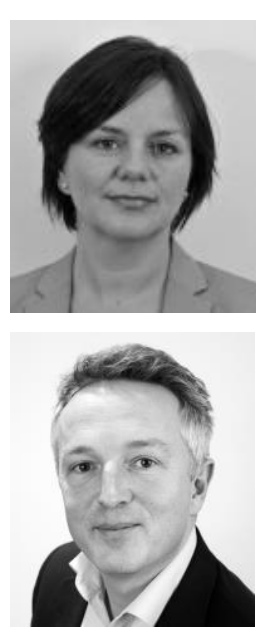

\section{Dr. Åse Gornitzka}

Åse Gornitzka is Professor at the Department of Political Science, University of Oslo, and Research Professor at Arena, Centre for European Studies, University of Oslo. She is also Adjunct Professor at the Department of Administration and Organization Theory, University of Bergen, and Editor-in-Chief of Scandinavian Political Studies. Her main fields of research include the role of organisational factors in EU governance, administrative integration and transformation in Europe, as well as the comparative study of national public reforms and change in public sector organisations.

\section{Dr. Ulf Sverdrup}

Ulf Sverdrup is the Director of the Norwegian Institute of International Affairs (NUPI). He holds a doctoral degree in Political Science from the University of Oslo. Before joining NUPI, he was a professor at the Norwegian Business School BI, and was also a Research professor at the ARENA, Centre for European Studies, University of Oslo. He has published extensively on various topics in international politics, with a particular emphasis on European governance and European integration. Sverdrup was the Head of the Secretariat for the Official Norwegian Europe Review (NOU 2012:2). 
Appendix. Regression models of inclusion of societal actors in the European Commission's expert groups. Logistic regression.

A.1 Social partners and Unions

\begin{tabular}{lcccc}
\hline $\mathbf{N = 1 1 2 7}$ & B & S.E. & Sig. & $\begin{array}{c}\text { Exp(B) } \\
\text { Odds ratio }\end{array}$ \\
\hline $\begin{array}{l}\text { Legal competences in policy area } \\
\text { DG main task (Spending=1, Else=0) }\end{array}$ &,- 108 &, 111 &, 332 &, 898 \\
$\quad$ Policy cycle &, 006 &, 224 &, 979 & 1,006 \\
$\quad$ - Assist in policy preparation &, 045 &, 220 &, 838 & 1,046 \\
$\quad$ - Coordinate/exchange views &, 833 &, 231 &, 000 & 2,300 \\
$\quad$ - Draft implementation &,- 302 &, 284 &, 289 &, 740 \\
$\quad$ - Monitoring national level &, 595 &, 257 &, 020 & 1,814 \\
$\quad$ Formal/informal group & 1,186 &, 193 &, 000 & 3,274 \\
$\quad \begin{array}{l}\text { Portfolio age } \\
\text { DG unit environment }\end{array}$ &, 028 &, 008 &, 001 & 1,028 \\
$\quad$ - Number of interest groups &, 004 &, 002 &, 049 & 1,004 \\
$\quad$ Constant & $-4,057$ &, 546 &, 000 &, 017 \\
\hline
\end{tabular}

A.2 Industry and Enterprise

\begin{tabular}{lcccc}
\hline $\mathbf{N}=1127$ & B & S.E. & Sig. & $\begin{array}{c}\text { Exp(B) } \\
\text { Odds ratio }\end{array}$ \\
\hline $\begin{array}{l}\text { Legal competences in policy area } \\
\text { DG main task (Spending=1, Else=0) }\end{array}$ &, 466 &, 105 &, 000 & 1,593 \\
$\quad$ Policy cycle & 1,082 &, 171 &, 000 & 2,950 \\
$\quad$ - Assist in policy preparation &, 566 &, 172 &, 001 & 1,761 \\
$\quad$ - Coordinate/exchange views &, 111 &, 171 &, 518 & 1,117 \\
$\quad$ - Draft implementation &, 180 &, 199 &, 367 & 1,197 \\
$\quad$ - Monitoring national level & $-1,098$ &, 258 &, 000 &, 333 \\
Formal/informal group &, 259 &, 157 &, 100 & 1,296 \\
$\quad \begin{array}{l}\text { Portfolio age } \\
\text { DG unit environment }\end{array}$ &, 017 &, 006 &, 002 & 1,011 \\
$\quad$ - Number of interest groups &, 011 &, 002 &, 000 &, 010 \\
Constant & $-4,582$ &, 478 &, 000 & \\
\hline
\end{tabular}

A.3 Consumer organisations

\begin{tabular}{lcccc}
\hline $\mathbf{N}=1127$ & B & S.E. & Sig. & $\begin{array}{c}\text { Exp(B) } \\
\text { Odds ratio }\end{array}$ \\
\hline $\begin{array}{l}\text { Legal competences in policy area } \\
\text { DG main task (Spending=1, Else=0) }\end{array}$ &, 930 &, 177 &, 000 & 2,534 \\
$\quad$ Policy cycle &,- 119 &, 337 &, 725 &, 888 \\
$\quad-$ Assist in policy preparation &,- 188 &, 286 &, 512 &, 829 \\
$\quad$ - Coordinate/exchange views &, 450 &, 299 &, 133 & 1,569 \\
$\quad$ - Draft implementation &, 056 &, 327 &, 865 & 1,057 \\
$\quad$ - Monitoring national level &,- 902 &, 493 &, 067 & 3,006 \\
$\begin{array}{l}\text { Permanent /temporary group } \\
\text { Formal/informal group }\end{array}$ & 1,101 &, 252 &, 000 & 1,821 \\
$\begin{array}{l}\text { Portfolio age } \\
\text { DG unit environment }\end{array}$ &, 599 &, 274 &, 029 & 1,018 \\
$\quad$ - Number of interest groups &, 018 &, 009 &, 046 & 1,016 \\
Constant & $-8,235$ &, 838 &, 000 &, 000 \\
\hline
\end{tabular}


A.4 Nongovernmental organisations

\begin{tabular}{|c|c|c|c|c|}
\hline$N=1127$ & B & S.E. & Sig. & $\begin{array}{c}\operatorname{Exp}(\mathrm{B}) \\
\text { Odds ratio }\end{array}$ \\
\hline Legal competences in policy area & ,075 & 104 & 471 & 1,078 \\
\hline$D G$ main task (Spending $=1, E l s e=0$ ) &,- 879 & 219 & ,000 & ,415 \\
\hline $\begin{array}{l}\text { Policy cycle } \\
\text { - Assist in policy preparation }\end{array}$ & -,132 & 191 & ,490 & ,876 \\
\hline - Coordinate/exchange views & 299 & 192 & 119 & 1,349 \\
\hline - Draft implementation & 166 & 219 & ,447 & 1,181 \\
\hline - Monitoring national level & 183 & 249 & ,461 & 1,201 \\
\hline Formal/informal group & ,385 & 176 & 029 & 1,469 \\
\hline Portfolio age &,- 009 & ,006 & 122 & ,991 \\
\hline $\begin{array}{l}\text { DG unit environment } \\
\text { - Number of interest groups }\end{array}$ &, 009 & ,002 & ,000 & 1,010 \\
\hline Constant & $-2,427$ &, 453 &, 000 & ,088 \\
\hline \multicolumn{5}{|l|}{ A.5 Practitioners-professional associations } \\
\hline$N=1127$ & B & S.E. & Sig. & $\begin{array}{c}\operatorname{Exp}(\mathrm{B}) \\
\text { Odds ratio } \\
\end{array}$ \\
\hline Legal competences in policy area &,- 088 & 114 & 441 & ,916 \\
\hline$D G$ main task (Spending $=1$, Else $=0$ ) &,- 195 & ,213 & ,360 & ,823 \\
\hline $\begin{array}{l}\text { Policy cycle } \\
\text { - Assist in policy preparation }\end{array}$ & ,667 & ,220 & ,002 & 1,947 \\
\hline - Coordinate/exchange views &,- 208 & ,215 & ,334 & ,812 \\
\hline - Draft implementation & ,268 & ,254 & 290 & 1,308 \\
\hline - Monitoring national level &,- 758 & 349 & ,030 & 469 \\
\hline Formal/informal group &,- 528 & ,232 & 023 & ,590 \\
\hline Portfolio age & ,008 & ,007 & ,272 & 1,008 \\
\hline $\begin{array}{l}\text { DG unit environment } \\
\text { - Number of interest groups }\end{array}$ & ,004 & ,002 & ,032 & 1,004 \\
\hline (Constant & $-2,312$ & ,520 & ,000 & 099 \\
\hline
\end{tabular}

